ACTA MYCOLOGICA

Vol. 42 (2): 193-198

2007
Dedicated to Professor Alina Skirgietto

on the occasion of her ninety-fifth birthday

\title{
New record of Phytophthora root and stem rot of Lavendula angustifolia
}

\author{
LESZEK B.ORLIKOWSKI ${ }^{1}$ and ALMA VALJUSKAITE ${ }^{2}$
}

${ }^{1}$ Research Institute of Pomology and Floriculture Pomologiczna 18, PL-96-100 Skierniewice, lorlikow@insad.pl ${ }^{2}$ Lithuanian Institute of Horticulture, Plant Protection Laboratory Babtai, Kauno 30, LT-54333

Orlikowski L.B., Valjuskaite A.: New record of Phytophthora root and stem rot of Lavendula angustifolia. Acta Mycol. 42 (2):193-198, 2007.

Phytophthora cinnamomi was isolated from rotted root and stem parts of lavender as well as from soil taken from containers with diseased plants. Additionally Botrytis cinerea, Fusarium spp. and Sclerotinia sclerotiorum were often isolated from diseased tissues. P. cinnamomi colonised leaves and stem parts of 4 lavender species in laboratory trials and caused stem rot of plants in greenhouse experiments. Cardinal temperature for in vitro growth were about 7,5 and $32^{\circ} \mathrm{C}$ with optimum $25-27,5^{\circ} \mathrm{C}$. The species colonised stem tissues at temperature ranged from $10^{\circ}$ to $32^{\circ} \mathrm{C}$.

Key words: stem rot, isolation, Phytophthora cinnamomi, colonisation, temperature, growth

\section{INTRODUCTION}

Lavender (Lavendula angustifolia Mill., syn. L.officinalis Chaix) is mainly medicinal and pharmaceutic plant but since the last years it has been grown in ornamental nurseries mainly as small, blooming, hedge culture. The quality of plants may be strongly decreased by Phytophthora species. From diseased plants mainly Phytophthora nicotianae var. parasitica was isolated (Pappas 1978; Putman 1991; Minuto et al. 2001a). Growing of plants in Italy under shade and in larger pots reduced disease incidence caused by that species (Min u t o et al.2001a). Variable resultswere obtained with susceptibility of cultivars or localselectionstoward the pathogen(M in u to etal.2001b).Pa e z etal.(1993)recovered P.palmivora Butler from diseased Lavendula dentata grown in Spanish gardens whereas Davino et al. (2002) isolated the species from rotted root of L. angustifolia in Italy.

In 2003 on lavender mother plants grown on greenhouse beds yellowing and browning of single shoots were observed. The disease spread slowly on neighbouring 
shoots. After the next 6 weeks $3 / 4$ parts of affected plants were destroyed (Fig.1). On mother plants dark-gray spots on the shoot bases, browning during the next few days and spreading on roots, upwards and on the periphery of affected stems were observed. The disease spread quickly on neighbouring mother plants and cuttings. On plants growing in container - grown nursery brown or dark-brown spots developed on individual shoots spread on roots and upwards. During the next 10 days single or a few yellow-brown to dark-brown shoots on individual plants were seen. The development of symptoms were observed during 2 years before or during flowering of plants. The objective of this investigation was to determine a causal agent of lavender shoot and root rot, development of disease in laboratory and greenhouse trials and relationship between temperature and growth of Phytophthora cinnamomi and colonisation of stem parts of plants.

\section{MATERIALS AND METHODS}

Survey of lavender in greenhouse and container - grown nursery. On plants grown in greenhouse shoot rot symptoms were observed only in one year on about $5 \%$ of lavender. In container - grown nursery lavender were grown at least 10 years but shoot and root rot symptoms occurred in years 2004 and 2005 on about 10 and $20 \%$,respectively. Diseased plants were collected in plastic bags and transferred to laboratory. The next day plants were removed from pots, substratum were collected in bags whereas plants were washed under tap water and affected shoots were separated, rinsed 3times in distilled water, blotting dried and chosen parts were sterilised over a burner flame. About $5 \mathrm{~mm}$ long stem parts were put on PDA medium and plates were checked during 4-day-incubation at $24^{\circ} \mathrm{C}$ in the dark on the presence of Phytophthora and other genera. Additionally, substratum samples, taken from pots with lavender showing disease symptoms in greenhouse and nursery, were analysed on the presence of Phytophthora spp. in years 2003-2005. Substratum taken from 3-6 pots was mixed about $5 \mathrm{~min}$ in plastic bag and half liter of it was put into plastic box, flooded with tap water (about 1 l) and rhododendron leaves cv. Zembla were floated over flooded sample (16 leaf blades/box). Boxes covered with plastic foil were incubated at temperature $22-24^{\circ} \mathrm{C}$. After 4-6-day-incubation leaves with necrotic spots were removed, washed with distilled water, blotted dried, disinfected over a burner flame and about $5 \mathrm{~mm}$ diameter plugs were transferred on PDA medium. Small parts of colonies, grown around tissues were transferred to PDA slants. Cultures from diseased stems and substratum were grouped on the base of their growth and morphology and chosen, representative isolates were identified to genera and species (Szku ta 2004). Confirmation of Phytophthora classification to species was performed by DNA analyses using the method described by Orlikowski et al. (2006).

Colonisation of lavender by Phytophthora cinnamomi. In laboratory trials leaves and stem parts of 4 cultivars of lavender (Tab. 1) were put into plastic boxes on sterilised, wet blotting paper covered with plastic net and inoculated with $3 \mathrm{~mm}$ plugs taken from the edge of 5-day-old cultures of P. cinnamomi (2 isolates from diseased stem base and substratum) growing on PDA at $24^{\circ} \mathrm{C}$ in the dark. Boxes were covered with foil and incubated at $22-24^{\circ} \mathrm{C}$ in the dark. After 5-day-incubation diameter and length of necrosis was measured. In greenhouse trial stem bases of 3 cultivars of lavender were inoculated with $3 \mathrm{~mm}$ diam plugs of $P$. cinnamomi (from diseased stem 
Table 1

Phytophthora cinnamomi isolated from substratum used for lavender growth; mean number of dark-brown spots on rhododendron leaves used as the bait

\begin{tabular}{|l|c|c|c|}
\hline Source of substratum & \multicolumn{3}{|c|}{ Year of analysis } \\
\hline & 2003 & 2004 & 2005 \\
\hline Greenhouse & $25.5 \mathrm{~b}$ & - & - \\
\hline Container nursery & $14.0 \mathrm{a}$ & $10.8 \mathrm{a}$ & $17.6 \mathrm{ab}$ \\
\hline
\end{tabular}

Note: Means followed by the same letter do not differ with 5\% of significance (Duncan's multiple range test)

base) and incubated under covering 12 days. Length of necrosis was measured 8 and 12 days after inoculation.

Relationship between temperature, ranged from 7,5 to $35^{\circ} \mathrm{C}$, growth of $P$. cinnamomi and colonisation of lavender stem parts by the species were studied using the same procedure like in laboratory trials.

Experimental design was completely randomised with 4 replications and 10 leaves, stem parts or plants in each rep. Growth of the species on PDA was estimated on the base of 5 Petri dishes for each temperature. Trials were repeated at least twice.

\section{RESULTS AND DISCUSSION}

Isolation of fungi and Algae-like Oomycetes. Similar genera and species were isolated from plants taken from greenhouse and field production (Tab. 2). From potential

Table 2

Fungi and Algae-like Oomycetes isolated from diseased base of Lavendula angustifolia; number of settled plants (a) and number of isolates obtained (b)

\begin{tabular}{|l|c|c|c|c|c|c|}
\hline \multicolumn{1}{|c|}{ Genera/species } & \multicolumn{3}{c}{ Year of isolation } \\
\hline & \multicolumn{2}{|c|}{$\begin{array}{c}2003 \\
\text { greenhouse } \\
\text { (27 plants) }\end{array}$} & \multicolumn{2}{c|}{$\begin{array}{c}2004 \\
\text { field (14 plants) }\end{array}$} & \multicolumn{2}{c|}{$\begin{array}{c}2005 \\
\text { field (21 plants) }\end{array}$} \\
\hline & a & b & a & b & a & b \\
\hline Alternaria alternata Nees & 2 & 5 & 6 & 11 & 8 & 13 \\
\hline Botrytis cinerea Pers. & 7 & 11 & 4 & 9 & 5 & 11 \\
\hline Cladosporium herbarum (Pers.) Link. & 3 & 3 & - & - & 2 & 4 \\
\hline Fusarium culmorum (W.G.Sm.) Sacc. & 4 & 7 & 2 & 5 & - & - \\
\hline Fusarium equiseti (Cda) Sacc. & 3 & 5 & - & - & 3 & 7 \\
\hline Fusarium solani (Mart.) Sny. et Hans. & 6 & 7 & 3 & 5 & 1 & 3 \\
\hline Humicola grisea Traaen & 1 & 2 & - & - & 2 & 5 \\
\hline Mucor spp. & 4 & 8 & 5 & 9 & 7 & 16 \\
\hline Penicillium spp. & 3 & 5 & 2 & 4 & - & - \\
\hline Phytophthora cinnamomi Rands & 18 & 56 & 9 & 29 & 18 & 44 \\
\hline Rhizopus sp. & - & - & 2 & 4 & - & - \\
\hline Sclerotinia sclerotiorum (Lib.) de Bary & 4 & 10 & - & - & 2 & 7 \\
\hline Trichoderma spp. & 3 & 6 & 3 & 7 & 4 & 7 \\
\hline
\end{tabular}


pathogens of lavender Botrytis cinerea (mainly in field), two Fusarium species, Phytophthora cinnamomi and Sclerotinia sclerotiorum were detected from diseased plant parts. P. cinnamomi (Fig.2) was the most often isolated species both, in greenhouse and field - grown plants. The species was detected from 3/4,5/7 and 6/7 of analysed plants, respectively (Tab. 2).

Isolation of Phytophthora cinnamomi from substratum. Using rhododendron leaves as the bait, $P$. cinnamomi was detected from substratum samples taken from 60 pots with plants showing Phytophthora rot symptoms. Significantly more necrotic spots were observed on rhododendron leaves floated in suspension of substratum collected from diseased lavender grown in greenhouse (Tab. 1).

Colonisation of lavender by Phytophthora cinnamomi. Both isolates of $P$. cinnamomi used for lavender inoculation in laboratory trials, caused necrosis of leaves and stem parts of 4 tested cultivars (Tab. 3). On stem parts necrosis spread faster than on leaves. In case of leaf blades inoculation, isolate from substratum colonised tissue slower than that from the stem base. On leaves of cv. Grosso necrosis spread at least $1 / 3$ faster than on 3 other cultivars. On stem parts such differences were not observed (Tab. 3).

Table 3

Colonisation of leaves and stem parts of lavender by Phytophthora cinnamomi; diam/length (in $\mathrm{mm}$ ) of necrosis after 5-day-incubation

Inoculation: 2005.09.27

\begin{tabular}{|c|c|c|c|}
\hline Source of $P$ c cinnamomi & Cultivars & Leaves & Stem parts \\
\hline Base of stem & Blue Dafo & $32.3 \mathrm{ab}$ & $43.3 \mathrm{a}$ \\
\hline & Edelweiss & $35.0 \mathrm{bc}$ & $40.3 \mathrm{a}$ \\
\hline & Grosso & $32.0 \mathrm{a}$ & $39.5 \mathrm{a}$ \\
\hline & Munstead & $35.5 \mathrm{c}$ & $38.8 \mathrm{a}$ \\
\hline & Blue Dafo & $19.5 \mathrm{~b}$ & $46.3 \mathrm{~b}$ \\
\hline & Edelweiss & $15.3 \mathrm{a}$ & $38.8 \mathrm{a}$ \\
\hline & Grosso & $30.8 \mathrm{c}$ & $45.3 \mathrm{ab}$ \\
\hline & Munstead & $22.5 \mathrm{~b}$ & $38.3 \mathrm{a}$ \\
\hline
\end{tabular}

Note: Means in columns followed by the same letter do not differ with $5 \%$ of significance; means separation for the source of the species

Table 4

Spread of necrosis (in mm) on lavender stems inoculated with Phytophthora cinnamomi from the stem base in relation to cultivars and incubation time; greenhouse trials Inoculation: 2005.1117

\begin{tabular}{|c|c|c|}
\hline Cultivars & \multicolumn{2}{|c|}{ Length of necrosis in mm after days of incubation } \\
\hline & 8 & 12 \\
\hline Blue Dafo & $66.5 \mathrm{~b}$ & $87.6 \mathrm{~b}$ \\
\hline Grosso & $53.4 \mathrm{a}$ & $73.7 \mathrm{ab}$ \\
\hline Munstead & $48.7 \mathrm{a}$ & $65.3 \mathrm{a}$ \\
\hline
\end{tabular}

Note: see Table 3 


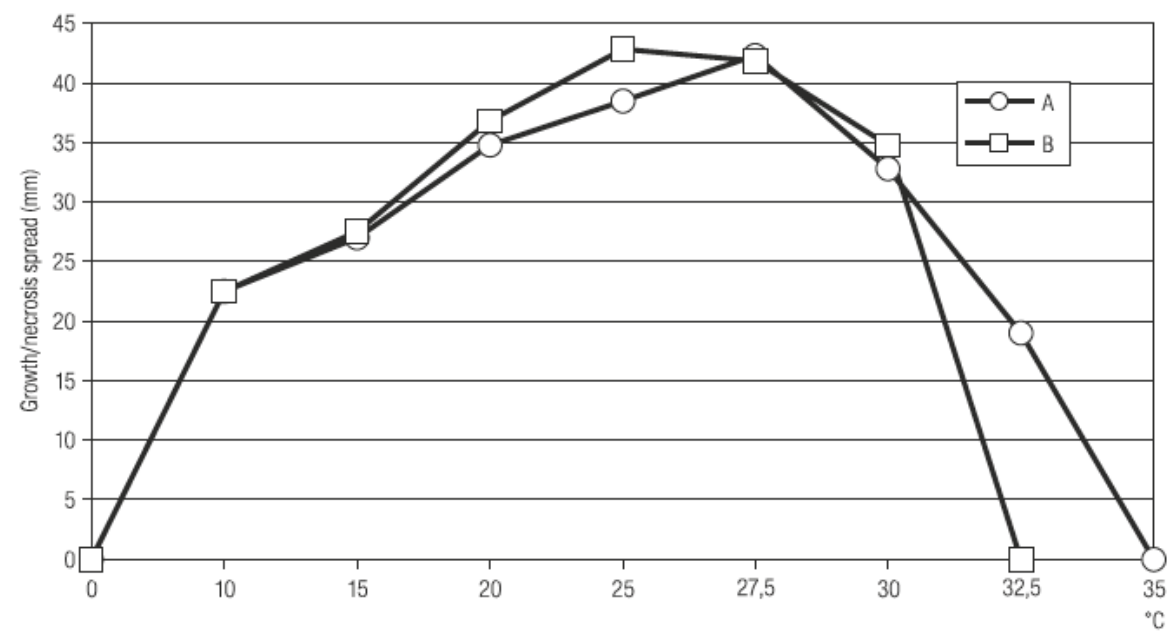

Fig. 3. Influence of temperature on in vitro growth of Phytophthora cinnamomi on PDA (A) and spread of necrosis on lavender stem parts inoculated with the species (B) after 6-dayincubation.

Inoculation of stem bases of lavender grown in greenhouse caused development of stem rot on 3 tested cultivars with significantly faster spread on cv. Blue Dafo than on other cultivars. Necrosis spread about $6,3 \mathrm{~mm} / 24 \mathrm{hr}$ (Tab. 4).

Studies of relationship between temperature, growth of $P$. cinnamomi and development of Phytophthora stem rot showed significant differences in observed parameters Cardinal temperature was about $7,5^{\circ}$ and $32,5^{\circ} \mathrm{C}$ with optimum at $25-27,5^{\circ} \mathrm{C}$. The species colonised stem parts at temperature ranged from $10^{\circ}$ to about $32,5^{\circ} \mathrm{C}$ with optimum at $25-27,5^{\circ} \mathrm{C}$ (Fig.3).

Our results indicated that among already recorded Phytophthora nicotianae var. nicotianae and $P$. palmivora in other countries, $P$. cinnamomi may be the next dangerous pathogen of lavender. Detection of the species on lavender grown under glass indicate that pathogen was probably brought with imported mother plants. In field - grown lavender the species could be spread from Chamaecyparis lawsoniana, grown in the same nursery and showing Phytophthora root and stem rot. The pathogen. was also found in water pond used for sprinkling of nursery plants and among them lavender (Orlikowski, unpubl). In favourable, greenhouse temperature $P$. cinnamomi colonised tissues and spread on lavender stem about 5,6 $\mathrm{mm} / 24$ $\mathrm{hr}$. Growing of lavender in containers under covering and in open field caused that during vegetation period substratum temperature is a few ${ }^{\circ} \mathrm{C}$ higher than in soil. Hogh temperature and regular watering of plants, usually 2-4 times/day during the summer, stimulate formation of zoosporangia and release of zoospores. Increase of the pathogen propagules number in substratum enlarge the probabilities of plant infection. 


\section{SUMMARY}

The objective of this investigation was to determine a causal agent of lavender shoot and root rot, development of disease on plant parts and relationship between temperature and growth of pathogen and disease development. During 3 years mycological analyse of diseased lavender, taken from greenhouse and container nursery, was done. Additionally, the presence of $P$. cinnamomi in substratum was estimated using rhododendron leaves as the bait. Phytophthora cinnamomi was isolated from the most of analysed plants and from substratum. Botrytis cinerea, Fusarium spp. and Sclerotinia sclerotiorum as other potential pathogens, were recovered from diseased shoot parts. Isolates of P. cinnamomi from plant and substratum colonised lavender leaves and stem parts of all tested cultivars. In greenhouse experiment the species quickly colonised stem tissues and necrosis spread about 5,6 $\mathrm{mm} / 24 \mathrm{hr}$. The growth of the pathogen on PDA and colonisation of stem parts were observed at temperature range from about 7,5 to $32,5^{\circ} \mathrm{C}$ with optimum $25-27,5^{\circ} \mathrm{C}$.

\section{REFERENCES}

Davino S., Cacciola S. O., Pennisi A. M., Destri Nicosia M. G. 2002. Phytophthora palmivora a new pathogen of lavender in Italy. Plant Disease 86 (5): 561.

Minuto A., Gullino M. L., Titone P., Garibaldi A. 2001. Influence of cultural practices on incidence of Phytophthora nicotianae var. parasitica causing root rot of lavender (Lavendula officinalis L.). Phytopathol. Meditterranea 40 (1): 45-54.

Minuto G., Armato B., Gilardi G., Garibaldi A. 2001. First observations on susceptibility of Lavendula spp. to Phytophthora nicotianae var. parasitica. Informatore Fitopatologico 51 (5):69-72.

Orlikowski L.B., Trzewik A., Wiejach a K. 2006. Phytophthora tropicalis, a new pathogen of ornamental plants in Poland. J. Plant Prot. Res. (in print).

Paez J. I., Berra D., Vega J. M., Tello J. 1993. Identification de Phytophthora palmivora Butler en jardines de la Exposicion Universal de Sevilla. Bol. de Sanidaad Vegetal, Plagas 19 (4): 633-447.

Papp as A. 1978. New diseases caused by Phytophthora spp. Phytophthora Newsl. 6: 72-73.

P u t n a m M. 1991. Root rot of lavender caused by Phytophthora nicotianae. Plant Pathol. 40: 480-482.

\section{Występowanie zgnilizny korzeni i pędów, powodowanej przez Phytophthora cinnamomi, na Lavendula angustifolia}

Streszczenie

Celem badań było określenie przyczyny zgnilizny pędów i korzeni lawendy, rozwoju choroby $w$ doświadczeniach laboratoryjnych i szklarniowych oraz współzależności pomiędzy temperaturą a wzrostem in vitro patogena oraz kolonizacją części łodyg. W ciągu 3 lat prowadzono analizę mikologiczną chorych roślin lawendy, pobieranych ze szklarni oraz ze szkółki pojemnikowej. Dodatkowo, stosując pułapki z liści różanecznika izolowano Phytophthora spp. z podłoża. Z większości chorych roślin, a także z podłoża izolowano Phytophthora cinnamomi. Z innych organizmów izolowano Botrytis cinerea, Fusarium spp. i Sclerotinia sclerotiorum. Izolaty $P$. cinnamomi z porażonej rośliny i podłoża kolonizowały liście i części łodyg wszystkich badanych odmian lawendy. W doświadczeniu szklarniowym omawiany gatunek szybko kolonizował tkanki pędów, a nekroza rozwijała się ok. 5,6 mm/ dobę. Wzrost $P$. cinnamomi na pożywce PDA oraz kolonizację pędów obserwowano w temperaturze od $7,5^{\circ}$ do $32,5^{\circ} \mathrm{C} \mathrm{z}$ optimum $25-27,5^{\circ} \mathrm{C}$. 


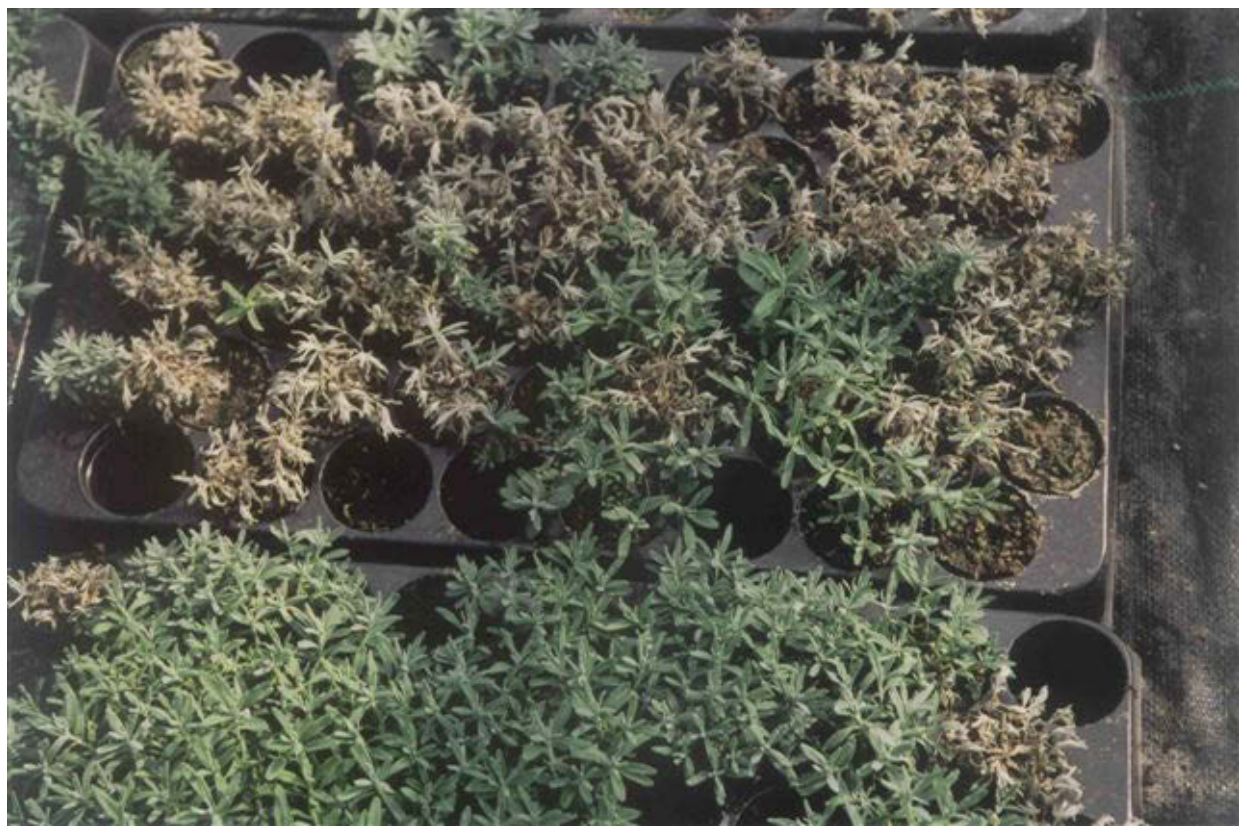

Fig.1. Phytophthora shoot and stem rot of lavender cuttings. Phot. L. B. Orlikowski.

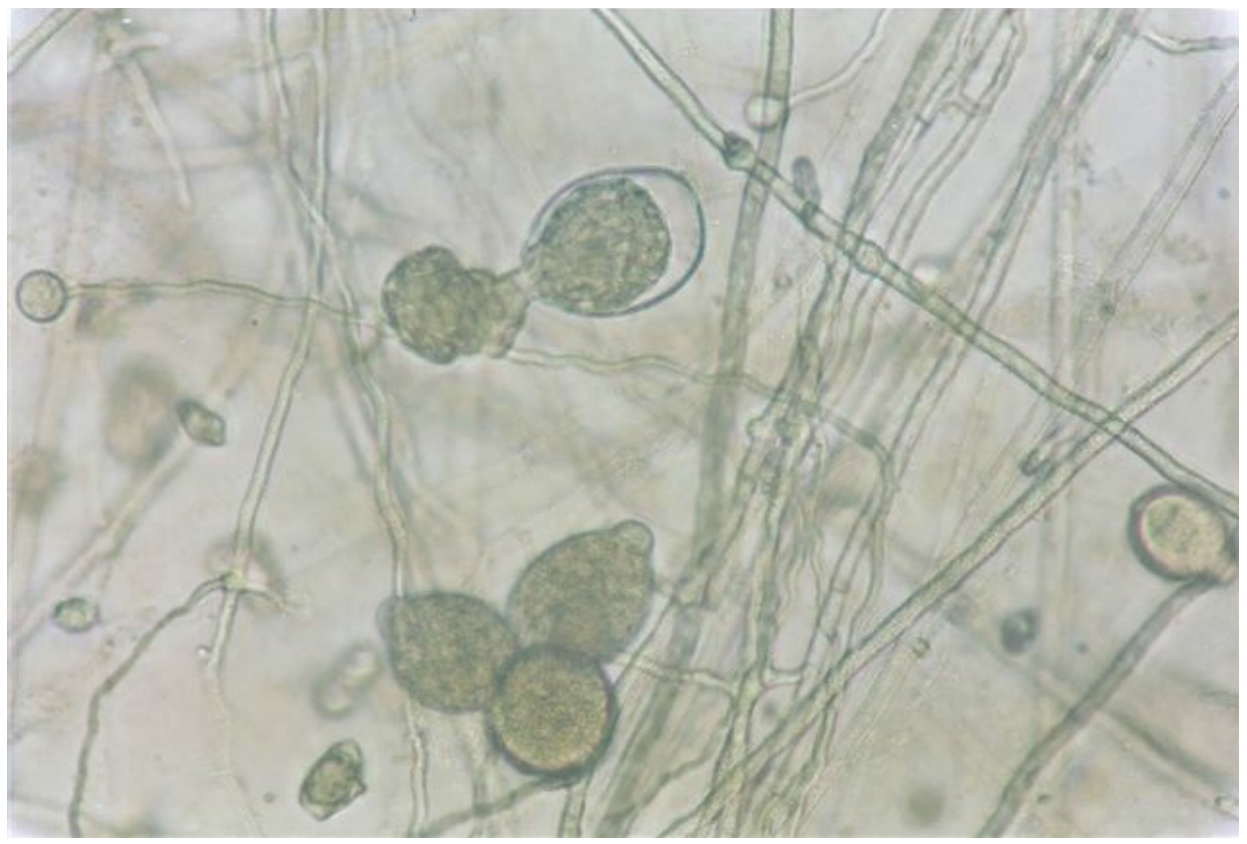

Fig. 2. Zoosporangia of Phytophthora cinnamomi and released zoospores. Phot. G. Szkuta. 